\title{
Information seeking Behavior of lecturers in Faculties of Education in Obafemi Awolowo University, Ile Ife and University of Ibadan \\ By \\ Sarah F. Akinola
}

\author{
National Centre for Technology Management Library, \\ Obafemi Awolowo University, \\ P.M.B 012, Ile-Ife \\ Nigeria.
}

\begin{abstract}
The study investigate the information seeking patterns and types of information sources used on the internet by lecturers in Faculties of Education in Obafemi Awolowo University, Ile Ife and University of Ibadan. The study employed the descriptive research method, using questionnaire for data collection. One hundred lecturers constituted the sample, comprising 54 from University of Ibadan and 46 from Obafemi Awolowo University. The study concluded that majority of the respondents from both universities seek information to update knowledge; 5.4 percent from U.I while 36 percent responded from O.A.U. The study recommended that the two University libraries should increase their internet bandwidth to improve their Internet speeds.
\end{abstract}

\section{Introduction}

Information seeking is as old as man himself. Man in his natural state is a curious being. Every individual, at one time or the other, consciously or unconsciously, partakes in the act of information seeking. This is usually done in the bid to answer the why, what, when and how questions, which prompts man to search through different information sources to satisfy his curiosity. Information sources are the materials or means through which information can be found. Information sources are numerous and that is what determines the quality of information at one's disposal.

The university remains a centre of excellence, citadel of learning, and more importantly the epitome of research. One of the underlining principles behind the existence of a university and its training is to equip students in the art of research, which is the bedrock of innovations. The Faculty of Education, being a very sensitive faculty, has become the rallying point in breeding future educators equipped in the in the act of re-producing tutors; hence, the place of research and information seeking could not be relegated to the background. It becomes imperative to dig deep into the information needs and information seeking of lecturers in the Faculty of Education and also study the pattern and strategies adopted to realize this goal.

The study of information needs and gathering behavior dates back to 1948 when Bernal and others presented a paper on scientific information at the 1948 Royal Society conference (Bernal, 1960).

During the past 30 years, a considerable body of literature has been produced dealing with information needs and information seeking pattern and strategies of both individuals and groups in a variety of contexts (Anwar, 2004). It is estimated that the number of publications on information seeking behaviour were more than ten thousand in the 1990s alone (Case, 2002). Many studies have been conducted to investigate the information seeking behaviour of library users based on their subject interests, occupation, information environment, and geographical location. Information needs and information seeking behaviour of academics have also been a popular area of research for the information scientists for decades (Majid and Kassim, 2000).

\section{The Concepts of Information Seeking}

Information seeking involves the need for the information, purpose for seeking for the information, the type of information being sought for, the sources consulted and the ways or methods employed in getting the information. It is a basic activity indulged in by all people and manifested through a particular behavior. It is also an aspect of scholarly work of most interest, especially to academic librarians who strive to develop collections, services, and organizational structures that facilitate information seeking (Wiberley, 1989). Mann (1993) notes that most researchers only find a fraction of the sources available to them despite the use of computers. He explains that researchers tend to work within one or another mental framework that limits their basic perception of the universe of knowledge available to them. Students according to him use a subject- 
disciplinary method that leads them to a specific list of sources on a particular subject.

He points out that while this method allows students and researchers to find more specific sources, it is limiting in that they may not realize that work of interest to their own subject appears within the literature of many other disciplines (Mann, 1993). This impinges on how much they get out of the library system. Information seeking is undertaken to identify a message that satisfies a perceived need (Wright and Guy, 1997). This activity may be actively or passively done when taking steps to satisfy a felt need (Ikoja-Odongo, 2002).

On the other hand, Anderson (2002) believes that information-seeking research looks at how individuals go about finding the materials that they need in order to satisfy informational needs that might be both professional and recreational. There are ways to study the information seeking pattern of people in our every-day life. For example, in the ethnographic experience of an unfamiliar worship service, an individual might gather clues about standing-sitting-kneeling through watching others, through listening for directions from an authority, or through written materials available somewhere in the place of worship. In the university, academics usually follow the patterns established by their peers, relying upon mentors in their fields to guide them in graduate school and early professional development.

Zhang (1998) stresses that a thorough understanding of user information needs and behavior are fundamental to the provision of successful information services. Wilson (1994) points out that the scope of information seeking behavior research is vast and many new concepts and methods are being developed with the help of this research. It is clear that the study of human information seeking behavior is now a well-defined area of research. According to Devadason and Lingman (1997), the understanding of information needs and information seeking behavior of various professional groups is essential as it helps in the planning, implementation, and operation of information system, and services in work settings.

The quality of a university will depend largely on its ability to attract highly qualified lecturers with outstanding performance and the competence of a university lecturer can be determined to a very large extent on the resources consulted in his research, teaching and community service work. As researchers, lecturers are expected to be creative and inquisitive. A teacher's research competencies can be judged by the number and quality of books and articles published (Opeke, n.d). Also, the vibrancy and effectiveness of the library officials is vital to the effective performance of lecturers in the act of information seeking.

\section{Obafemi Awolowo University, Ile-Ife}

The Obafemi Awolowo University, Ile-Ife was founded in 1962 as the University of Ife and was renamed Obafemi Awolowo University in May 1987 in honour of Obafemi Awolowo, the first premier of the Western region of Nigeria who was also the University's founding statesman and first chancellor. Obafemi Awolowo University offers undergraduate and postgraduate programmes in various field of specialization spanning the humanities, arts, natural sciences, social sciences, medical sciences, engineering and technology. The university currently has 13 faculties and two colleges of health sciences administered in more than 60 departments.

The Faculty of Education, which is the focus of this research, currently has seven departments manned by lecturers. These departments are Education Foundations and Counselling (EFC); Continuing Education; Educational Administration and Planning; Physical Education; Institute of Education; Educational Technology; Special Educational and Curriculum Studies. Each of these departments comprises many courses, running into hundreds of courses being offered in the faculty. While the Faculty of Education, Obafemi Awolowo University has seven departments.

\section{University of Ibadan, Ibadan}

University of Ibadan was the first Nigerian University established in 1948. The University was originally instituted as an independent external college of the University of London then it was called the University College, Ibadan. The University of Ibadan became an independent university in 1962. Hon. Sir Abubakar Tafawa Balewa, first Prime Minister of independent Nigeria, became the first Chancellor of the University, while the first Nigerian vice chancellor of the university was Professor Kenneth Dike, after whom University of Ibadan's library is named.

The Faculty of Education, University of Ibadan has nine departments. They are Department of Adult education; Educational Management; Guidance \& Counselling; Teacher Education; Library, Archival \& Information Studies; Human Kinetics and Health Education; Special Education; Social Work and Literacy Training Developments Programme for Africa (CLTDPA). The modes of recruitment into 
these faculties are similar, as they recruit lecturers from graduate assistant level.

\section{Statement of the Problem}

Lecturers irrespective of their status carry out research at one time or the other. The main thrust of this study can be summarized in the work of Hounsell (1979) when he established that only a few teachers engage in active information seeking and many do not understand the concept of specific enquiring for information; that some teachers lack the knowledge about their existence of information sources. The information seeking pattern of lecturers in this 'Internet Age' is a source of interest to this study. The extent to which lecturers in the two universities has maximized the opportunities of this new trend of information seeking strategies is also relevant. In addition the way and manner lecturers organize their search for academic information is very crucial to their overall academic performance and their productivity.

\section{Objective of the Study}

The objectives of the study are to:

i. To identify information seeking patterns of lecturers in Faculties of Education in Obafemi Awolowo University, Ile Ife and University of Ibadan

ii. To identify the type information sources used on the Internet by lecturers in in Faculties of Education in Obafemi Awolowo University, Ile Ife and University of Ibadan

\section{Significance of the Study}

The knowledge of the information seeking pattern of lecturers is crucial for an effective services delivery, hence the finding of the study will help the libraries to design information systems and services that will better meet the information needs of lecturers.

\section{Information Seeking behavior of Lecturers}

Case (2002) defines information seeking as a conscious effort to acquire information in response to a need or a gap in your knowledge. Informationseeking research looks at how individuals go about finding the materials that they need in order to satisfy their informational needs. Information seeking is a basic activity indulged in by all people and manifested through a particular behavior. It is also an aspect of scholarly work. The strategies employed by lecturers in carrying out their research are different in their information seeking. A Strategy is a long term plan of action designed to achieve a particular goal, most often "winning." Strategy is differentiated from tactics or immediate actions with resources at hand by its nature of being extensively premeditated, and often practically rehearsed. Strategies are used to make the problem easier to understand and solve.

From previous research, in the university, academics usually follow the patterns established by their peers, relying upon mentors in their fields to guide them in their professional development. Lecturers have their own methods of conducting research, of engaging their colleagues, of seeking information, and of disseminating information in their respective fields. Differences of style come from both the individual-his or her own personal traits, predispositions, and biases, and from the training that he or she has received in a particular discipline (Andersen, 2002). The type of information a lecturer searches for is tailored after his needs, which invariably is as a result of his area of specialization, this was justified by the Akusu (1987) when he said that information need differs according to one's area of specialization. Information need is also an individual or group's desire to locate and obtain information to satisfy a conscious or unconscious need.

According to Case (2000) information need is a recognition that your knowledge is inadequate to satisfy a goal that you have. The type of information a user needs depends on the user of the information. Information seeking arises from the fact that an individual needs information, whether to satisfy a present need or a future need, he is required to consult some information sources. The quality and quantity of information an individual has access to, is as a result of the information sources available at his disposal.

Lecturers fall under one of the categories of information users as categorized by Aina (2004). Lecturers are a group of researchers that seek information to assist them in their academic work most importantly to prepare lecture materials to support their teaching, self-development and also to know the latest development in their field. Lecturers also had to demonstrate strong research prowess, as well as sound teaching and administrative skills. A lecturer that fails to consult different information sources but rather relies only on his residual knowledge or a textbook will find himself in an embarrassing situation when confronted by his students.

\section{Information Seeking Pattern of Academics}

Many scholars have pointed out that the studies on information seeking strategies and needs of social scientists are fewer than those involving the natural sciences, and the studies of humanists' information 
needs are fewer still (Line, 1969; Hopkins, 1989; Blazek, 1994; Challener, 1999).

Elbert noted the differences in journal use between scholars in different disciplines in his assertion that: scientists generally require current material and use information obtained in specific projects; engineers and applied scientists employed for duties other than research read journals more for general information and stimulation. Historians and anthropologists want currents material, but they also need documents and journals dating back many years.

In Pakistan, a number of studies on reading habits of different professional groups have been carried out by various individuals, associations, and institutions which partly indicate their need of information. Anwar (2007) reviewed different research studies on information needs and information seeking behaviour of different groups of people in Pakistan. He mentioned fifteen unpublished studies conducted on the subject so far. Shahzad (2007) conducted a survey to find out the information seeking behaviour of faculty members of Government College University, Lahore. He acquired the data from all three faculties, i.e., science and technology, social sciences and humanities.

Anjum (1978) studied the information needs of humanities lecturers at the University of the Punjab. Knowledge of the information needs and information seeking behaviour of users is vital for developing library collections, upgrading facilities, and improving services to effectively meet the information needs of users. A review of the related literature reveals that no comprehensive study on the information needs and information seeking behaviour of arts and humanities faculty members at the University of the Punjab, Lahore has been conducted since 1978. Shokeen and Kushik (2002), for instance, studied about information seeking behaviour of social scientists working in the universities located in Haryana. They reported most of the social scientists visit the library daily. The first preferred method of searching the required information by the social scientists followed by searching through indexing and abstracting periodicals, and citations in articles respectively. The social scientists use current journals followed by books.

A researcher (Challener, 1999) investigated artists and art historians teaching in five liberal arts colleges and three universities and the results found that they need information for teaching. The participants almost all subscribe to art journals, and many read newspapers. They visit libraries frequently, usually more than one library, and unlike previous reports, the majorities are willing to ask the librarian for help. A large percentage of both art historians and artists are using computers for teaching. All twenty seven (27) participants use slides extensively in the classroom, supplemented in most cases by textbooks.

Reneker (1992) investigated the information seeking activities of thirty one (31) members of the Stanford University academic community were examined over a two-week period during the 1990-91 academic year. She adopted the naturalistic approach and employed qualitative techniques for the data collection focusing mainly on personal interviews. Informants' perception of their information environment is expressed in positive terms, and there is a close relationship between knowledge of the information environment and the sources used. Information seeking is embedded in the day-to-day activities and relationships of the participants and is triggered both by the articulation of need and availability of information. A large number of needs are satisfied by sources the informants created or organized themselves and by interpersonal information sources. The findings of the study indicated that the action of information seeking originated from a wide variety of needs like personal, professional, entertainment, etc.

\section{Data Analysis And Interpretation}

One hundred and nine (109) respondents were selected from the two universities; University of Ibadan and Obafemi Awolowo University, Ile-Ife on ratio 60:60. That is 60 percent of the lecturers in Faculty of Education in University of Ibadan and 60 percent of the lecturers in the Faculty of Education in Obafemi Awolowo University. Of the One hundred and nine (109) lecturers sampled, one hundred (100) completed and returned the questionnaire. The under listed frequency tables contain the details of the data collected and analyzed.

\section{Socio-Demographic Characteristics of Respondents \\ Table 1: Distribution of Respondents by their Institution}

\begin{tabular}{crrrr}
\hline & \multicolumn{2}{c}{ U.I } & \multicolumn{2}{c}{ O.A.U } \\
\hline Institutions & 54 & $54.0 \%$ & 46 & $46.0 \%$ \\
\hline
\end{tabular}

Sources: Field survey 2009

The above table shows that 54 percent of the respondents were from University of Ibadan while 46 percent were from Obafemi Awolowo University. The difference in the number of respondents may not 
be unconnected with the fact that there are more lecturers in the Faculty of Education in University of Ibadan than O.A.U.

Information Seeking Pattern of the Respondents Table 2: Frequency of Information Seeking

\begin{tabular}{|c|c|c|c|c|}
\hline & \multicolumn{2}{|c|}{ U.I } & \multicolumn{2}{|c|}{ O.A.U } \\
\hline & $\mathrm{N}=54$ & $\%$ & $N=46$ & $\%$ \\
\hline Daily & 39 & 72.2 & 32 & 69.6 \\
\hline $\begin{array}{l}\text { At least once a } \\
\text { week }\end{array}$ & 13 & 24.1 & 13 & 28.3 \\
\hline No response & 2 & 3.7 & 1 & 2.2 \\
\hline \multicolumn{5}{|c|}{$\begin{array}{l}\text { Sources: Field survey } 2009 \\
\text { As seen from the result of the analysis, majority from } \\
\text { the two universities seek information daily followed } \\
\text { by those that said at least once in a week that is, they } \\
\text { seek information on weekly basis. }\end{array}$} \\
\hline
\end{tabular}

information include; writing of papers or books, reading, and for preparing class lectures.

Table 4: Type of Materials sought in the University Library

\begin{tabular}{lcccc} 
& \multicolumn{2}{c}{ U.I } & \multicolumn{2}{c}{ O.A.U } \\
& $\mathbf{N}=\mathbf{5 4}$ & \% & N=46 & \% \\
\hline Textbooks & 27 & 34.6 & 24 & 37.4 \\
\hline Periodicals & 31 & 39.7 & 27 & 42.2 \\
\hline Newspapers & 8 & 10.3 & 5 & 7.8 \\
\hline Exhibitions & 3 & 3.8 & - & - \\
\hline $\begin{array}{l}\text { Government } \\
\text { Publications }\end{array}$ & 7 & 9 & 6 & 9.4 \\
\hline Reference books & 1 & 1.3 & 1 & 1.6 \\
\hline Pamphlets & 1 & 1.3 & 1 & 1.6 \\
\hline
\end{tabular}

Sources: Field survey 2009

*Multiple responses

As depicted in table 8, about 2 out of every 5 O.A.U lecturers from U.I and O.A.U do consult textbook and periodicals for the purpose of their research $\mathbf{N = 5 4} \quad$ \% $\quad \mathbf{N = 4 6} \quad \%$ work. Some of them also do consult newspaper.

Table 5: Frequency of Materials Used

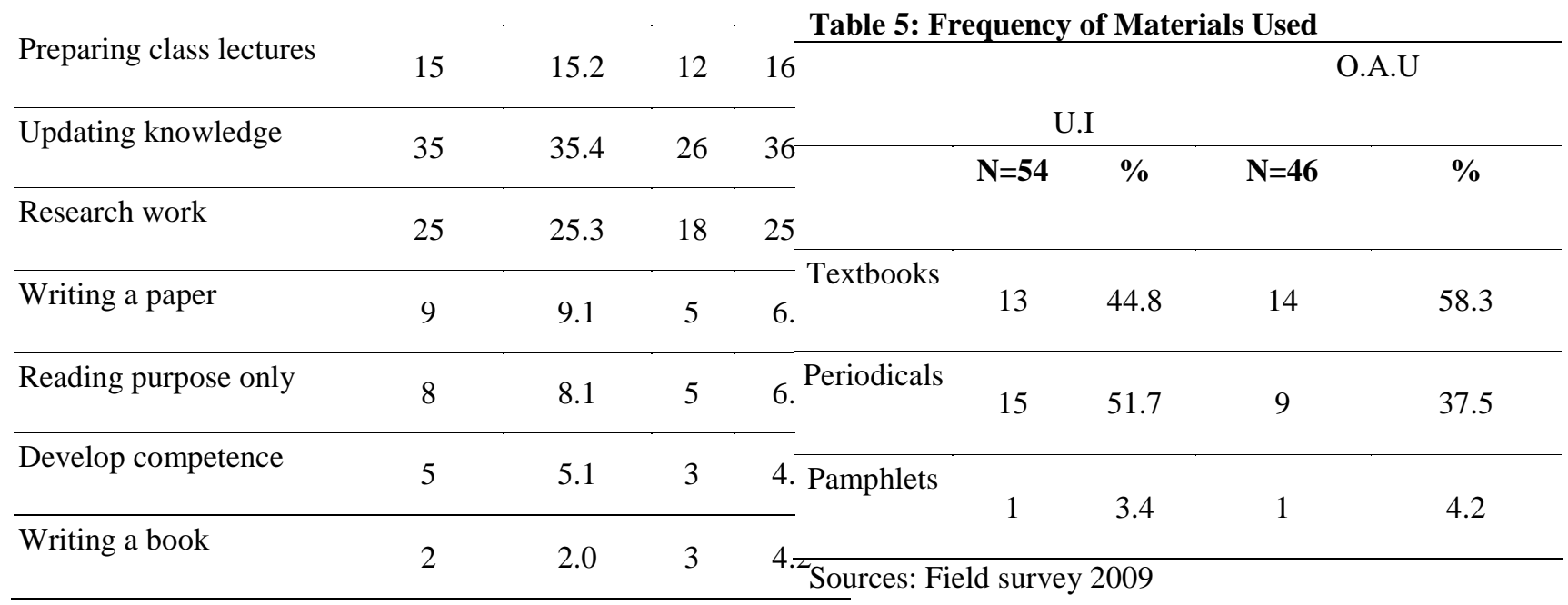

Sources: Field survey 2009

The findings shows that majority of the respondents from both universities seek information to update knowledge, 35.4 percent from U.I while 36 percent responded from O.A.U. One out of every four lecturers from the 2 universities seeks information for their research works. Other purposes for seeking
The results shows that periodicals are the most frequently consulted information materials in U.I (51.7 percent). Majority of the respondents in O.A.U frequently consult textbooks(58.3 percent) as seen from the above table, pamphlets is not often consulted by lecturers. 
Table 4.17: Type of Information Sources used on the Internet

\begin{tabular}{|c|c|c|c|c|}
\hline & & & \multicolumn{2}{|c|}{ O.A.U } \\
\hline & \multicolumn{2}{|c|}{ U.I } & & \\
\hline & $\begin{array}{c}N=5 \\
4\end{array}$ & $\%$ & $\mathrm{~N}=46$ & $\%$ \\
\hline $\begin{array}{l}\text { Individual (personal) } \\
\text { webpages }\end{array}$ & 3 & 3.9 & - & - \\
\hline Electronic journals & 36 & 46.8 & 29 & 47.5 \\
\hline $\begin{array}{l}\text { Webpages of } \\
\text { professional } \\
\text { Organisations and } \\
\text { associations }\end{array}$ & 18 & 23.4 & 17 & 27.9 \\
\hline $\begin{array}{l}\text { Electronic conferences } \\
\text { (newsgroups) }\end{array}$ & 13 & 16.9 & 10 & 16.4 \\
\hline $\begin{array}{l}\text { Webpages of conferences } \\
\text { and congresses }\end{array}$ & 4 & 5.2 & 2 & 3.3 \\
\hline No response & 3 & 3.9 & 3 & 4.9 \\
\hline
\end{tabular}

Sources: Field survey 2009

*Multiple responses

As seen from the findings, the most significant professional information type that was often sought by most lecturers was electronic journals followed by webpage of professional organizations.

Table 7: Purpose of Using the Internet

\begin{tabular}{|c|c|c|c|c|}
\hline & & & \multicolumn{2}{|c|}{ O.A.U } \\
\hline & $\mathrm{N}=54$ & $\%$ & $\mathrm{~N}=46$ & $\%$ \\
\hline Education & 31 & 45.6 & 29 & 50.9 \\
\hline Entertainment & 8 & 11.8 & 6 & 10.5 \\
\hline Health & 5 & 7.4 & 2 & 3.5 \\
\hline Sports & 5 & 7.4 & 3 & 5.3 \\
\hline News & 19 & 27.9 & 17 & 29.8 \\
\hline
\end{tabular}

Sources: Field survey 2009 *Multiple responses
Looking critically at the table above, majority of the respondents' from the two institutions seek information from the Internet for educational purposes.

Table 4.11: Place of Accessing the Internet O.A.U

\begin{tabular}{lcccc}
\multicolumn{5}{c}{ U.I } \\
\hline & $\mathbf{N}=\mathbf{5 4}$ & \% & $\mathbf{N}=\mathbf{4 6}$ & \% \\
\hline Home & 6 & 9.5 & 5 & 9.4 \\
\hline Office & 44 & 69.8 & 37 & 69.8 \\
\hline Library & 3 & 4.8 & 2 & 3.8 \\
\hline $\begin{array}{c}\text { Cyber } \\
\text { café }\end{array}$ & 10 & 15.9 & 9 & 17.0
\end{tabular}

Sources: Field survey 2009 *Multiple responses

The result above shows that majority of the respondents from the two institutions access the internet from their offices. 69.8 percent of the respondents access the Internet from their offices in U.I while it is 69.8 percent in O.A.U accesses the Internet. Next to this was from the cybercafé; U.I 15.9 percent and O.A.U 17 percent only few from both Universities had access to the internet at home.

Table 4.12: Respondents' Frequency of Internet Use

\begin{tabular}{cccc}
\hline & UI & \multicolumn{2}{c}{ O.A.U } \\
\hline $\mathrm{N}=54$ & $\%$ & $\mathrm{~N}=46$ & $\%$
\end{tabular}

\section{Daily}

$37 \quad 68.5 \quad 30$

65.2

\begin{tabular}{lcccc}
\hline $\begin{array}{l}\text { At least once a } \\
\text { week }\end{array}$ & 9 & 16.7 & 12 & 26.1 \\
\hline $\begin{array}{l}\text { At least once a } \\
\text { fortnight }\end{array}$ & 1 & 1.9 & 1 & 2.2 \\
\hline $\begin{array}{l}\text { No response } \\
7\end{array}$ & 13.0 & 3 & 6.5 \\
\hline Sources: Field survey 2009 & *Multiple responses
\end{tabular}


As seen from the result of the findings above, majority of the respondents from the two universities used internet daily while other significant response was at least once in a week.

Table 4.13: Use of Paid Electronic Resources by Respondents'

\begin{tabular}{ccccc}
\hline & \multicolumn{4}{c}{ O.A.U } \\
\hline UI & & & \\
\hline $\mathrm{N}=5$ & $\%$ & $\mathrm{~N}=4$ & $\%$ \\
4 & & 6 & \\
\hline
\end{tabular}

\begin{tabular}{lcccc}
\hline $\begin{array}{l}\text { I use only resources } \\
\text { available free of charge }\end{array}$ & 13 & 23.6 & 11 & 23.9 \\
\hline $\begin{array}{l}\text { The access is provided by } \\
\text { library or other institution }\end{array}$ & 14 & 25.5 & 10 & 21.7 \\
\hline $\begin{array}{l}\text { I pay for the access to } \\
\text { some resources myself }\end{array}$ & 28 & 50.9 & 25 & 54.3 \\
\hline $\begin{array}{l}\text { Sources: Field survey 2009 } \\
\text { *Multiple responses }\end{array}$
\end{tabular}

The table above shows that responses of the respondents on this table differ slightly, 23.6 percent from U.I used only resources available free of charge while it is 23.9 percent in O.A.U. 25.5 percent from U.I used access provided by library or other institution while it was 21.7 percent from O.A.U also 50.9 percent from U.I pay for the access to some resources themselves while O.A.U respondents with the same opinion was 54.3 percent.

Table 4.16: Tools used in searching for information

\begin{tabular}{|c|c|c|c|c|}
\hline & \multicolumn{2}{|c|}{ U.I } & \multicolumn{2}{|c|}{ O.A.U } \\
\hline & $N=54$ & $\%$ & $\mathrm{~N}=46$ & $\%$ \\
\hline Library catalogue & 18 & 28.6 & 19 & 35.8 \\
\hline Indexing journals & 10 & 15.9 & 7 & 13.2 \\
\hline $\begin{array}{l}\text { Abstracting } \\
\text { journals }\end{array}$ & 9 & 14.3 & 3 & 5.7 \\
\hline $\begin{array}{l}\text { References from a } \\
\text { book }\end{array}$ & 14 & 22.2 & 11 & 20.8 \\
\hline $\begin{array}{l}\text { References from a } \\
\text { periodical article }\end{array}$ & 9 & 14.3 & 10 & 18.9 \\
\hline Books reviews & 3 & 4.8 & 3 & 5.7 \\
\hline
\end{tabular}

Sources: Field survey 2009 *Multiple responses

As seen from the findings, 28.6 percent from U.I used the Library catalogue, while 35.8 percent of their counterpart from O.A.U used the Library catalogue, also 15.9 percent from U.I make use of Indexing journals and 13.2 percent from O.A.U said same. 14.3 percent from U.I used Abstracting journals while 5.7 percent in O.A.U, 20.0 percent from O.A.U used References from books and 22.2 percent in U.I. 4.8 percent from U.I used the review books while 5.7 percent from O.A.U also used book review.

Table 4.20: Search Engine used in the process of seeking information by respondents

\begin{tabular}{|c|c|c|c|c|}
\hline & \multicolumn{2}{|c|}{ U.I } & \multicolumn{2}{|c|}{ O.A.U } \\
\hline & $\mathrm{N}=54$ & $\%$ & $\mathrm{~N}=46$ & $\%$ \\
\hline Google.com & 36 & 58.1 & 31 & 58.5 \\
\hline Yahoo.com & 10 & 16.1 & 8 & 15.1 \\
\hline $\begin{array}{l}\text { Altavista.co } \\
\mathrm{m}\end{array}$ & 4 & 6.5 & 4 & 7.5 \\
\hline $\begin{array}{l}\text { Webcrawler. } \\
\text { com }\end{array}$ & 5 & 8.1 & 6 & 11.3 \\
\hline MSN.com & 4 & 6.5 & 4 & 7.5 \\
\hline Others & 3 & 4.8 & 3 & 0.1 \\
\hline
\end{tabular}

Majority of the respondents from the analysis in the above table shows that Google.com is the most frequently used search engine (58.1 percent from U.I and 58.5 percent from O.A.U) than other search engine. Other search engines indicated by respondents are mam.com, ask.com, JSTOR and Wikipedia. 
Table 4.21: Criteria used in Evaluating the Relevance of Document Searched

\begin{tabular}{|c|c|c|c|c|}
\hline & $\mathbf{U}$ & & \multicolumn{2}{|c|}{ O.A.U } \\
\hline & $\mathrm{N}=54$ & $\%$ & $N=46$ & $\%$ \\
\hline Titles & 24 & 29.3 & 20 & 31.2 \\
\hline Authors & 32 & 39.0 & 25 & 39.1 \\
\hline Annotations & 3 & 3.7 & - & - \\
\hline Keywords & 10 & 12.2 & 9 & 14.1 \\
\hline Contents & 1 & 1.2 & - & - \\
\hline $\begin{array}{l}\text { Titles of } \\
\text { chapters }\end{array}$ & 6 & 7.3 & 5 & 7.8 \\
\hline $\begin{array}{l}\text { Structure of } \\
\text { text }\end{array}$ & 1 & 1.2 & - & - \\
\hline Indexes & 1 & 1.2 & 1 & 1.6 \\
\hline Citations & 4 & 4.9 & 4 & 6.2 \\
\hline
\end{tabular}

Sources: Field survey 2009 *Multiple responses

The analysis in table 23 above shows that majority of the respondents (39 percent from U.I and 39.1 percent from O.A.U) used authors as the criteria in judging the relevance of a document searched closely followed by title of materials.

\subsection{Problems Encountered in The Process of Seeking Information}

Table 4.22: Document that have helped in Information Problem

\begin{tabular}{|c|c|c|c|c|}
\hline & \multicolumn{2}{|c|}{ U.I } & \multicolumn{2}{|c|}{ O.A.U } \\
\hline & $\mathrm{N}=54$ & $\%$ & $N=46$ & $\%$ \\
\hline $\begin{array}{l}\text { Articles in professional } \\
\text { periodicals }\end{array}$ & 22 & 36.1 & 19 & 40.4 \\
\hline Encyclopedia & 5 & 8.2 & 2 & 4.3 \\
\hline Monographs & 2 & 3.3 & 1 & 2.1 \\
\hline Dictionaries & 5 & 8.2 & 3 & 6.4 \\
\hline Theses & 1 & 1.6 & - & - \\
\hline Research reports & 4 & 6.6 & 1 & 2.1 \\
\hline $\begin{array}{l}\text { Search engines on } \\
\text { Internet }\end{array}$ & 22 & 36.1 & 21 & 44.7 \\
\hline
\end{tabular}

Sources: Field survey 2009

*Multiple responses

Looking at the result of findings above, majority of the respondents' from both universities relied on search engines on the internets to solve their information problem. This is closely followed by articles in professional periodicals 
Table 4.23: Problems encountered by respondents during information search complain that a lot of relevant information is through subscription and payment.

\section{O.A.U}

\section{Recommendation}

Based on the research carried out on lecturers' information seeking pattern in the Faculty of \begin{tabular}{lllllllll}
\hline Non-availability & of & & & & Education Obafemi Awolowo University and the \\
information & 26.4 & 17 & 25.8 & University of Ibadan, the following recommendations
\end{tabular} $\begin{array}{llllllll}\text { information materials } & 23 & 26.4 & 17 & 25.8 & \text { are hereby made for general improvement of }\end{array}$

\begin{tabular}{lccccc}
\hline $\begin{array}{l}\text { Lackadaisical } \\
\text { library staff }\end{array}$ & attitude of & 8 & 9.2 & 6 & 9.1 \\
\hline $\begin{array}{l}\text { Incomplete information } \\
\text { materials }\end{array}$ & 4 & 4.6 & - & - \\
\hline Lack of time & 11 & 12.6 & 7 & 10.6 \\
\hline $\begin{array}{l}\text { Do not know how to use the } \\
\text { catalogue }\end{array}$ & 1 & 1.1 & - & - \\
$\begin{array}{l}\text { Too many class lecture } \\
\text { lectures and administrative } \\
\text { work }\end{array}$ & 11 & 12.6 & 9 & 13.6 \\
$\begin{array}{l}\text { Information scattered in too } \\
\text { many sources }\end{array}$ & 10 & 11.5 & 11 & 16.7 \\
\hline \begin{tabular}{l} 
Information is too vast \\
\multicolumn{1}{c}{ of information }
\end{tabular} & 11 & 12.6 & 11 & 16.7 \\
\hline $\begin{array}{l}\text { Some } \\
\text { materials are old }\end{array}$ & 2 & 2.3 & - & - \\
\hline Any other problem & & & 5 & 7.6 \\
\hline
\end{tabular}

Sources: Field survey 2009

*Multiple responses

As seen from the table above, the most significant reported problem from both universities was non availability of information materials, percentage distribution of respondents' from U.I was 26.4 percent while those from O.A.U 25.8 percent followed by information scattered in too many sources.

\section{Conclusion}

This study was undertaken to examine the information seeking pattern of lecturers, investigate their predominant source of information. The increase in information available on the Internet has greatly affected the information seeking pattern of lecturers. Their pattern of searching for and gathering information is expressed in various methods, through electronic sources, consulting knowledgeable person in the field and preference to the use of periodicals in their university libraries. Their offices remain the location point for accessing the Internet. The findings show that most lecturers even though prefer the use of electronic resources and Internet sources experience slow Internet connection speed. They also information services rendered to them.

i. That the University library should be well stocked with relevant and recent journals to keep lecturers abreast of developments in their various field.

ii. The Management of the two Institutions increases their Internet bandwidth since this study has revealed that their usage of internet sources is very high. This will invariably save the time of the lecturers while using the Internet

iii. That electric power is provided at all times by the two tertiary Institution s especially because Internet sources are mostly preferred and access to its sources is mostly from their offices. This is usually done in the morning probably before attending to class lectures or administrative work.

\section{REFERENCES}

Aina, L.O. 2004. Library and information science text for Africa. Ibadan: Third world information services.

Anjum, M.A. K. 1978. Information needs of university teachers of the Punjab. MSc. Project. Dept. of Library and Information Science. University of Punjab, Lahore

Anwar, M.A. 2007. Research on information seeking and use in Pakistan: an assessment. Pakistan Journal of Library and Information Science. 8: $15-32$

Atherton, P. 1979. Handbook of Information Systems and Service. Paris: UNESCO. P.10

Anderson, D.L. 2002. Communicating information across cultures: understanding how others work. New York. Retrieved Nov. 28, 2008 from http://www.pantaneto.co.uk/issue9/andersen.ht $\mathrm{m}$ 
Bates, M.J. 2001. "Information needs and seeking of scholars and artists in relation to multimedia materials," at http://www.gseis.ucla.edu/faculty/bates/schola rs.html. Retrieved Nov. 25 November 2008

Case, D.O. 2002. Looking for information... In Brophy $\mathrm{P}$ et al. 2004. EDNER: Formative Evaluation of the Distributed National Electronic Resource: Stakeholder consultation and analysis - user information needs. Manchester: CERLIM (The Centre for Research in Library \& Information Management. Retrieved Oct. 20, 2008 from http://www.cerlim.ac.uk/projects/edner.htm

Devadason, F. J and Lingman, P. P. 1997. A methodology for the identification of information needs of Users, IFLA Journal. 23.1: 41-51.

Ikoja-Odongo, J.R. 2002. An observational study of the information seeking and communicating behavior of entrepreneurs in the informal sector of Uganda In: Bothma, T. and A. Kaniki. ProLISSA 2002: Proceedings of the second biennial DiSSAnet conference, 24-25 October. Pretoria: Infuse. 11-28

Mann, T. 1993. Library research models: A guide to classification, cataloguing and computers. New York: Oxford University Press.

Majid, S and Kassim, G. M. 2000. Behaviour of international Islamic university Malaysia Law Faculty Members. Malaysian Journal of Library \& Information Science 5.2: 1-17

Okpeke, R.O. n. d. Academic staff professional development for optimal productivity.
Retrieved March 5, 2009 from http://www.babcockuni.edu.ng/userfiles/ACA DEMIC\%20STAFF\%20PROFFESSIONAL\% 20DEVELOPMENT\%20FOR.ppt

Patitungkho, K and Deshpande, N.J. 2005. Information seeking behaviour of Faculty members of Rajabhat universities in Bangkok. Webology. 2.2. Retrieved Nov. 25, 2008 from http://www.webology.ir/2005/v2n4/a20.html

Shahzad, K. 2007. Information Seeking Behavior of Government College University Teacher: A survey. MSc. Project. Dept. of Library and Information Science, University of the Punjab, Lahore

Wiberley, S.E and Jones, W.G. 1989. Patterns of Information Seeking in the Humanities. College \& Research Libraries. 50. 6: 638645.

Wright, M. and Guy, L., 1997. "Where do I find it and what do I do with it: Practical problemsolving in the data library. Retrieved Nov. 6 2002 from http://dphs.dacc.wisc.edu/types/data_reference .html

Zubair, A. 2009. Professional competence achievable through improved quality law education. The Guardian. Jan. 20:81

Zauwa, J. 1992 The Information needs of academic staff in non-University technologically-based tertiary institutions in Benue State. Journal of the Nigerian Library Association. 25\&26.1-4 :21-35.

Zhang, W. 1998. Analyzing faculty and staff's information needs and use of electronic technologies: a liberal arts college's experiences. Journal of Education Media and Library Sciences 3.3: 218-24 